\title{
Biodegraded magnetosomes with reduced size and heating power maintain a persistent activity against intracranial U87-Luc mouse GBM tumors
}

Edouard Alphandéry ${ }^{1,2^{*}}$, Ahmed Idbaih ${ }^{3}$, Clovis Adam ${ }^{4}$, Jean-Yves Delattre ${ }^{3}$, Charlotte Schmitt ${ }^{3}$, Florence Gazeau ${ }^{5}$, François Guyot ${ }^{1,6}$ and Imène Chebbi ${ }^{2}$

\begin{abstract}
Background: An important but rarely addressed question in nano-therapy is to know whether bio-degraded nanoparticles with reduced sizes and weakened heating power are able to maintain sufficient anti-tumor activity to fully eradicate a tumor, hence preventing tumor re-growth. To answer it, we studied magnetosomes, which are nanoparticles synthesized by magnetotactic bacteria with sufficiently large sizes ( $30 \mathrm{~nm}$ on average) to enable a follow-up of nanoparticle sizes/heating power variations under two different altering conditions that do not prevent anti-tumor activity, i.e. in vitro cellular internalization and in vivo intra-tumor stay for more than 30 days.

Results: When magnetosomes are internalized in U87-Luc cells by being incubated with these cells during $24 \mathrm{~h}$ in vitro, the dominant magnetosome sizes within the magnetosome size distribution (DMS) and specific absorption rate (SAR) strongly decrease from DMS $\sim 40 \mathrm{~nm}$ and SAR $1234 \mathrm{~W} / \mathrm{g}_{\mathrm{Fe}}$ before internalization to DMS $11 \mathrm{~nm}$ and SAR $\sim 57 \mathrm{~W} / \mathrm{gFe}$ after internalization, a behavior that does not prevent internalized magnetosomes to efficiently destroy U87-Luc cell, i.e. the percentage of U87-Luc living cells incubated with magnetosomes decreases by 25\% between before and after alternating magnetic field (AMF) application. When $2 \mu \mathrm{l}$ of a suspension containing $40 \mathrm{\mu g}$ of magnetosomes are administered to intracranial U87-Luc tumors of $2 \mathrm{~mm}^{3}$ and exposed (or not) to 15 magnetic sessions (MS), each one consisting in $30 \mathrm{~min}$ application of an AMF of $27 \mathrm{mT}$ and $198 \mathrm{kHz}$, DMS and SAR decrease between before and after the $15 \mathrm{MS}$ from $\sim 40 \mathrm{~nm}$ and $\sim 4 \mathrm{~W} / \mathrm{g}_{\mathrm{Fe}}$ down to $\sim 29 \mathrm{~nm}$ and $\sim 0 \mathrm{~W} / \mathrm{g}_{\mathrm{Fe}}$. Although the magnetosome heating power is weakened in vivo, i.e. no measurable tumor temperature increase is observed after the sixth MS, anti-tumor activity remains persistent up to the 15th MS, resulting in full tumor disappearance among $50 \%$ of treated mice.
\end{abstract}

Conclusion: Here, we report sustained magnetosome anti-tumor activity under conditions of significant magnetosome size reduction and complete loss of magnetosome heating power.

Keywords: Chains of magnetosomes, Magnetotactic bacteria, Glioblastoma, U87-Luc, Antitumor efficacy, Magnetic hyperthermia, Nanomedicine, Oncology, Nanotherapy, Nanooncology, Alternating magnetic field, Thermotherapy, Hyperthermia, Magnetic hyperthermia

*Correspondence: edouardalphandery@hotmail.com

${ }^{1}$ Institut de minéralogie et de Physique Des matériaux et de

Cosmochimie, UMR 7590 CNRS, Sorbonne Universités, UPMC, University

Paris 06, Muséum National D’Histoire Naturelle, 4 Place Jussieu,

75005 Paris, France

Full list of author information is available at the end of the article

c) The Author(s) 2019. This article is licensed under a Creative Commons Attribution 4.0 International License, which permits use, sharing, adaptation, distribution and reproduction in any medium or format, as long as you give appropriate credit to the original author(s) and the source, provide a link to the Creative Commons licence, and indicate if changes were made. The images or other third party material in this article are included in the article's Creative Commons licence, unless indicated otherwise in a credit line to the material. If material is not included in the article's Creative Commons licence and your intended use is not permitted by statutory regulation or exceeds the permitted use, you will need to obtain permission directly from the copyright holder. To view a copy of this licence, visit http://creativeco mmons.org/licenses/by/4.0/. The Creative Commons Public Domain Dedication waiver (http://creativecommons.org/publicdomain/ zero/1.0/) applies to the data made available in this article, unless otherwise stated in a credit line to the data. 


\section{Background}

Cancer thermotherapies currently in use in hospital such as high intensity focused ultrasound necessitate high heating temperatures (typically $80-90{ }^{\circ} \mathrm{C}$ ) to be efficient, resulting in a number of side effects [1]. To prevent them, the treatment can be carried out at more moderate temperatures or even without any measurable temperature increase by using an external source of energy such as an alternating magnetic field (AMF) applied on nanoparticles contained in a tumor. The latter approach has been tested with various nano-therapeutic systems, leading to encouraging results $[2,3]$, notably in the treatment of glioblastoma by magnetic hyperthermia $[4,5]$. In order to be optimal, such treatments necessitate that nanoparticles remain for a sufficiently long time in the tumor to induce strong and persistent anti-tumor activity until full tumor disappearance. At the same time, nanoparticles also need to be eliminated. Their long-term accumulation in a specific part of the organism should be avoided. Such a fine adjustment of nanoparticle bio-distribution properties can be obtained by using nanoparticles that are progressively captured and degraded by the organism [6, 7]. However, such behavior is often associated with a reduction in size, crystallinity, heating power, and anti-tumor efficacy of nanoparticles [8]. To the author knowledge, it has not yet been shown that nanoparticles could remain efficient against a tumor after significant alteration.

Here, we study a certain type of nanoparticles, called magnetosomes, which are synthesized by magnetotactic bacteria (AMB-1) and are composed of a mineral iron oxide core surrounded by a layer consisting of biological material, mainly consisting of lipids, proteins, and lipopolysaccharides [9-16]. Anti-tumor activity has been demonstrated upon injection of magnetosomes and application of alternating magnetic fields [14-17]. Magnetosomes possess a well-balanced size distribution with $58 \%$ of them larger than $30 \mathrm{~nm}$ and $42 \%$ of them smaller than $30 \mathrm{~nm}$ (Table 1) [10]. This size distribution enables the observation of changes in magnetosome sizes under various conditions of alteration in vitro and in vivo. Here, we study whether altered magnetosomes can yield antitumor activity both in vitro by examining if magnetosomes internalized in U87-Luc tumor cells can destroy these cells and in vivo by monitoring the decrease in bioluminescence intensity (BLI) emitted by U87-Luc tumors implanted in mouse brains, which are injected with magnetosomes and exposed to 15 sessions of alternating magnetic field application. Furthermore, we also examine the link between magnetosome size alteration, antitumor activity, and weakening of heating power.

\section{Results and discussion}

Magnetosome properties (size distribution, heating power, and endotoxin release) prior to their administration

Here, we study the properties of nanoparticles, called magnetosomes, which are synthesized by magnetotactic bacteria, of which a typical transmission electron microscopy (TEM) image is presented in Fig. 1a.

The preparation of the injectable magnetosome suspension involved the following steps: (i), growth of AMB-1 Magnetospirillum magnetotacticum magnetotactic bacteria (ATCC 700264) during 7 days, (ii), harvesting of a concentrated pellet of these bacteria, (iii), lysis of these bacteria under sonication at $0{ }^{\circ} \mathrm{C}$ during $2 \mathrm{~h}$ at $30 \mathrm{~W}$, (iv), isolation of magnetosome chains (CM) from cellular organic debris using a magnet, (v), re-suspension of $\mathrm{CM}$ in a sterile injectable solution containing $5 \%$ of glucose, and (vi), partial sterilization of the CM suspension by exposing CM suspension to UV irradiation for $12 \mathrm{~h}$.

The stability of $\mathrm{CM}$ in suspension, which is required to carry out in vitro and in vivo studies, is revealed, firstly by the behavior of the zeta potential variation of this suspension as a function of $\mathrm{pH}$ that displays a welldefined and repeatable behavior, i.e. a decrease from $20 \mathrm{mV}$ at $\mathrm{pH} 2$ to $-35 \mathrm{mV}$ at $\mathrm{pH} 12$ (Additional file 1: Figure S1a), and secondly by the optical absorption of this suspension, measured at $480 \mathrm{~nm}$, which decreases moderately, i.e. by less than $30 \%$ within 20 min following homogenization of this suspension (data not shown). Magnetosome composition was reported to consist of an iron oxide mineral core surrounded by biological material, containing endotoxins made of lipopolysaccharides (LPS), which binds magnetosomes together [18, 19]. On the one hand, such composition was deduced from infrared absorption measurements carried out on a lyophilized suspension of $\mathrm{CM}$, denatured and dispersed in $\mathrm{KBr}$, whose infra-red absorption spectra displayed (Fig. 1b): (i), Amide I and Amide II bands due to protein absorption at $1650 \mathrm{~cm}^{-1}$ and $1530 \mathrm{~cm}^{-1}$ [20-22], (ii), absorption bands due to lipopolysaccharide (LPS) or phospholipids contained in the magnetosome membrane at $1050 \mathrm{~cm}^{-1}$ and $1250 \mathrm{~cm}^{-1}[20,21]$, (iii), a peak at $580 \mathrm{~cm}^{-1}$ attributed to maghemite [22], as reported elsewhere [22]. CHNS elemental analysis of CM revealed a percentage of $13.9 \%$ of carbonaceous material surrounding the magnetosome mineral core (Additional file 1: Figure S1b). Furthermore, part of the organic material surrounding the iron oxide mineral core of the magnetosomes is composed of endotoxins, as highlighted by limulus amebocyte lysate (LAL) measurements carried out on a CM suspension that shows the presence of $2000 \mathrm{EU}$ of endotoxins per $\mathrm{mg}$ in iron per $\mathrm{ml}$ of CM suspension. Magnetosome size distributions are measured by analysis 
Table 1 Percentages of magnetosomes smaller than $30 \mathrm{~nm}$, percentages of magnetosomes larger than $30 \mathrm{~nm}$, and dominant magnetosome sizes within the whole magnetosome size distribution for untreated magnetosomes, magnetosomes internalized in U87-Luc cells, magnetosomes administered to intracranial U87-Luc tumors without magnetic treatment, or magnetosomes injected to intracranial U87-Luc tumors followed by 15 magnetic sessions during which an AMF of $198 \mathrm{kHz}$ and $27 \mathrm{mT}$ is applied during $30 \mathrm{~min}$

\begin{tabular}{|c|c|c|c|}
\hline & $\begin{array}{l}\text { Percentage } \\
\text { of magnetosomes } \\
\text { smaller than } 30 \mathrm{~nm}\end{array}$ & $\begin{array}{l}\text { Percentage } \\
\text { of magnetosomes } \\
\text { larger than } 30 \mathrm{~nm}\end{array}$ & $\begin{array}{l}\text { Dominant } \\
\text { magnetosomes size } \\
\text { DMS }(\mathrm{nm})\end{array}$ \\
\hline Untreated magnetosomes & 42 & 58 & 40 \\
\hline Internalized magnetosomes (in vitro) & 92.5 & 7.5 & 11 \\
\hline $\begin{array}{l}\text { Magnetosomes administered in U87-Luc tumors and kept in the } \\
\text { tumors for } 30 \text { days without AMF application }\end{array}$ & 23.5 & 76.5 & 43 \\
\hline $\begin{array}{l}\text { Magnetosomes administered in intracranial U87-Luc tumors followed } \\
\text { by } 15 \mathrm{MS}\end{array}$ & 64 & 36 & 29 \\
\hline
\end{tabular}

of TEM images of a dried suspension of CM deposited on top of a carbon-coated TEM grid, such as those presented in Fig. 1c, d. The distribution displays two peaks centered at $22 \pm 4.6 \mathrm{~nm}$ and $40 \pm 2.7 \mathrm{~nm}$ with a mean size at $37.5 \pm 5.2 \mathrm{~nm}$ (Fig. 1e), resulting in nanoparticles of sufficiently large sizes to yield a ferrimagnetic behavior at room temperature, i.e. with $\mathrm{H}_{\mathrm{C}} \sim 20 \mathrm{mT}$ and $\mathrm{M}_{\mathrm{r}}$ / $\mathrm{M}_{\mathrm{S}} \sim 0.3$ (Additional file 1: Figure S1c), and therefore also strong heating power (Additional file 1: Figure S1d) [9]. The latter was measured for suspensions of magnetosomes in water under two conditions: $2 \mathrm{mg}$ of magnetosomes contained in $100 \mu \mathrm{l}$ of water (condition 1) and $40 \mu \mathrm{g}$ of magnetosomes suspended in $2 \mu \mathrm{l}$ of water (condition 2), the same quantities of magnetosomes as those used for in vitro and in vivo experiments, which were exposed to the one MS, i.e. the application of an AMF of $198 \mathrm{kHz}$ and average strength $27 \mathrm{mT}$ during $600 \mathrm{~s}$. The SAR was estimated using the formula $\mathrm{SAR}=(\Delta \mathrm{T} /$ $\delta \mathrm{t}) \cdot\left(\mathrm{C}_{\mathrm{v}} / \mathrm{X}_{\mathrm{Fe}}\right)$, where $\mathrm{C}_{\mathrm{v}}=4.2 \mathrm{~J} / \mathrm{gK}$ is the specific heat capacity of water, $\mathrm{X}_{\mathrm{Fe}}=20 \mathrm{mg} / \mathrm{ml}$ (conditions 1 and 2), $\Delta \mathrm{T} / \delta \mathrm{t}=5.9 \pm 1.5{ }^{\circ} \mathrm{C} / \mathrm{s}$ (condition 1 ) and $\Delta \mathrm{T} / \delta \mathrm{t}=9.5 \times$ $10^{-3} \pm 1.8 \times 10^{-3}{ }^{\circ} \mathrm{C} / \mathrm{s}$ (condition 2). Interestingly, the first condition of treatment yielded much larger SAR and temperature increase over the whole $\mathrm{MS}(\Delta \mathrm{T})$, i.e. $\mathrm{SAR}=1234 \pm 307 \mathrm{~W} / \mathrm{g}_{\mathrm{Fe}}$ and $\Delta \mathrm{T}=95 \pm 8{ }^{\circ} \mathrm{C}$, than the second one, i.e. $\mathrm{SAR}=57 \pm 6 \mathrm{~W} / \mathrm{g}_{\mathrm{Fe}}$ and $\Delta \mathrm{T}=33 \pm 3{ }^{\circ} \mathrm{C}$ (Table 2). These results suggest that for an equivalent magnetosome concentration (here $20 \mu \mathrm{g} / \mu \mathrm{l}$ ), magnetosome heating power decreases with decreasing volume comprising magnetosomes. Although such behavior is rarely reported in the literature, possibly due to the use of adiabatic heating conditions that are far from the real in vivo heating environment, it could be due to enhanced heat diffusion between the interior and exterior of the magnetosome suspension, which is willingly contained in a non-adiabatic Eppendorf, due to larger surface to volume ratio when magnetosomes are contained in a smaller volume. This result suggests a mechanism by which magnetosome heating power is improved when magnetosomes become distributed within a larger volume, a situation that may occur in vivo when magnetosomes distribution becomes scattered within the whole tumor over time. Since magnetosome anti-tumor activity could come not only from a purely thermal effect but also from an immune reaction triggered by endotoxin release, the effect of the application of the same MS as above on magnetosome endotoxin release was studied. Interestingly, magnetosomes continue to release endotoxins after AMF application. Indeed, moderate endotoxin release is measured in the supernate of suspensions of magnetosomes following one MS. Endotoxin release is estimated as $\mathrm{Q}_{\mathrm{AMS}} / \mathrm{Q}_{\mathrm{BMS}} \sim 0.5 \%$, where $\mathrm{Q}_{\mathrm{AMS}}$ and $\mathrm{Q}_{\mathrm{BMS}}$ are the quantities of endotoxins contained in the supernate of a $\mathrm{CM}$ suspension after and before one $\mathrm{MS}$ for $\mathrm{Q}_{\mathrm{AMS}}$ and $\mathrm{Q}_{\mathrm{BMS}}$, respectively.

\section{Magnetosome internalization inside U87-Luc cells results in a decrease of magnetosome sizes, heating power, while maintaining a faculty to destroy these cells} Next, we study the effect of magnetosome cellular internalization on magnetosome sizes, heating power, and anti-tumor activity. For that, $2 \mathrm{ml}$ of suspensions of magnetosome, containing $1.4 \mathrm{mg}$ of iron, were incubated with U87-Luc cells during $24 \mathrm{~h}$ followed (or not) by one MS during which an AMF of $27 \mathrm{mT}$ and $198 \mathrm{kHz}$ was applied during $30 \mathrm{~min}$. To verify that such treatment resulted in magnetosome cellular internalization, we carried out optical microscopic observations of assemblies of cells and magnetosomes stained with Prussian blue. They reveal a cyan coloration at cell location, which is more persistent after than before one MS (inset of Fig. 2a), suggesting that magnetosome internalization is enhanced following one MS. Such behavior is further supported by estimating the percentage of iron internalized in cells, using ICP-AES iron dosage carried out on these assemblies dissolved by Nitric acid. It increases from 1.5\% before one MS to $9.2 \%$ 


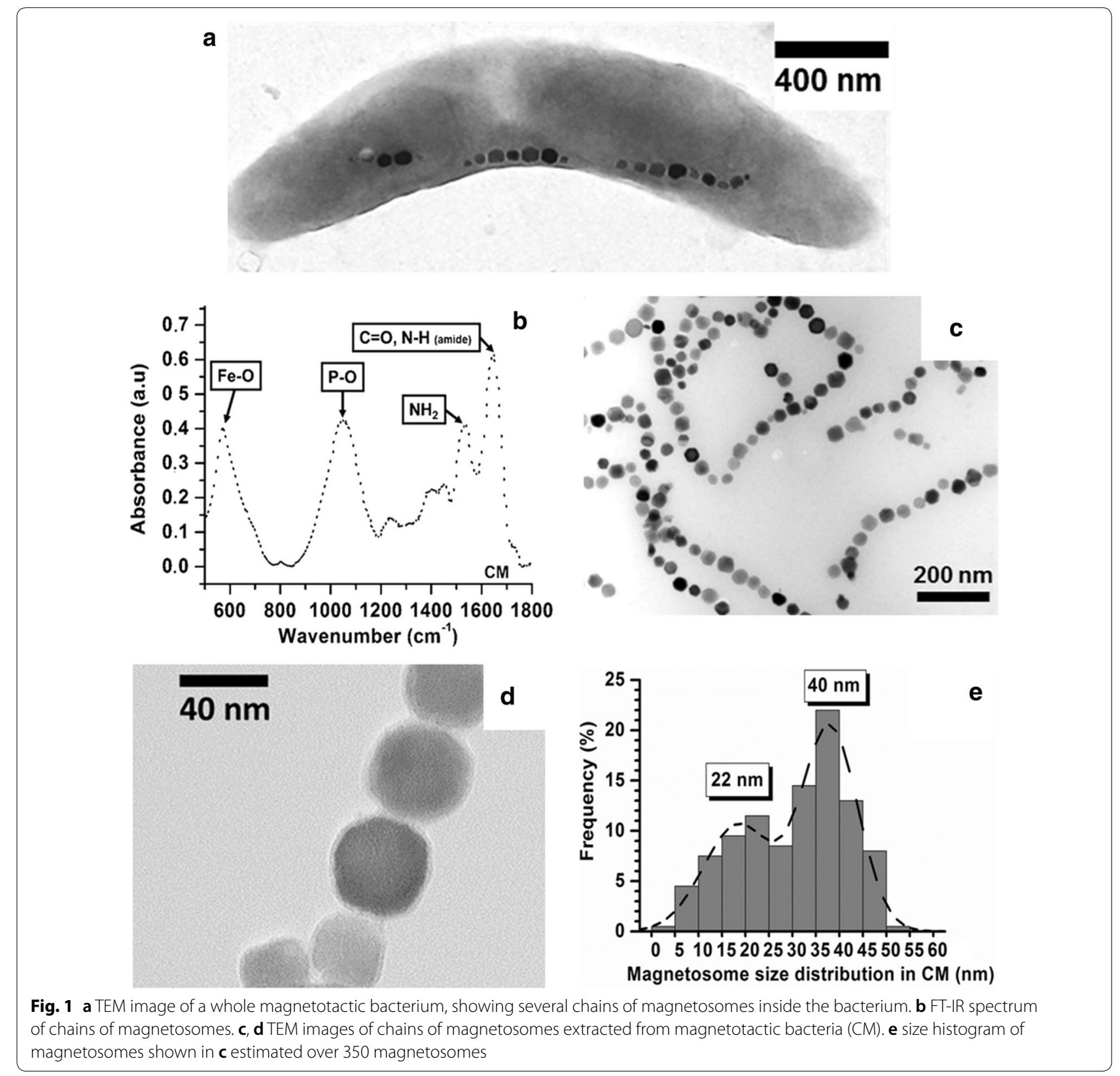

after one MS. To examine more precisely magnetosome location following internalization, the cells brought into contact with magnetosomes were cut with a diamond knife in an ultra-microtome in $80 \mathrm{~nm}$ thin slices. The latter were deposited on top of a carbon-coated TEM grid and examined by TEM. Under these conditions of treatment, the TEM images of Fig. 2b, c show that magnetosomes are localized inside a cellular vesicle of $0.2-0.5 \mu \mathrm{m}$, which is most probably a lysosome or an endosome. The effect of cellular degradation on size and organization of magnetosomes can also be observed in these electron microscopy images. Indeed, compared with magnetosomes of Fig. 1c that were not treated, i.e. kept in water suspension, those of Fig. 2b, c appear to have lost their organization in chains, to have acquired for some of them a different shape, as observed in Fig. 2b, c, and to have become smaller. Indeed, their size distribution shows that $92.5 \%$ of them are below $30 \mathrm{~nm}$ while $7.5 \%$ of them are above $30 \mathrm{~nm}$ (Table 1). The size distribution displays two peaks centered at $11 \pm 1.8 \mathrm{~nm}$ and $36 \pm 8.6 \mathrm{~nm}$ with a mean size at $12 \pm 7.9 \mathrm{~nm}$ (Fig. 2c). These observations indicate a magnetosome degradation following cellular internalization. Furthermore, this intracellular degradation is accompanied by a loss of heating power, as revealed by the measurements of SAR and 


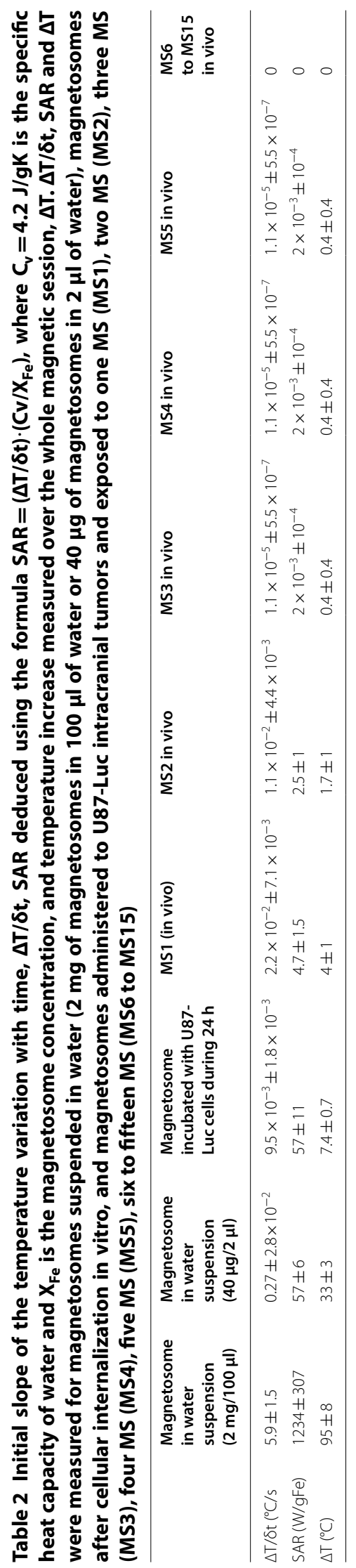



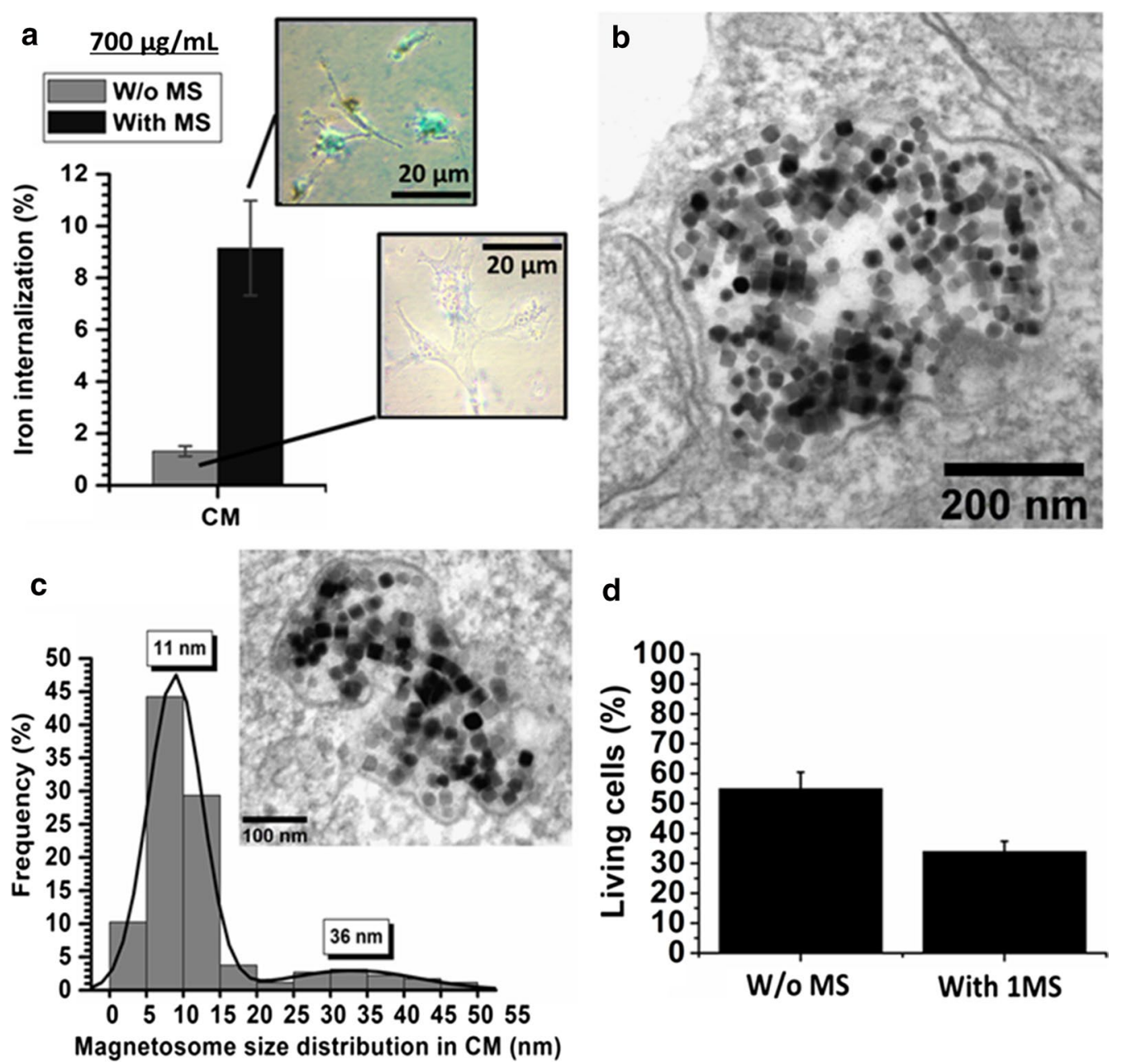

Fig. 2 a Percentage of iron internalized in U87-Luc cells measured by ICP-AES, when these cells were brought into contact with $700 \mu \mathrm{g} / \mathrm{ml}$ of CM during $24 \mathrm{~h}$, and either not subjected to one MS (w/o MS) or subjected to one MS (with MS). In the inset of $\mathbf{a}$, optical microscopy images of cells brought into contact with CM and stained with Prussian blue. b, c TEM images and associated size histogram estimated on 150 magnetosomes of magnetosomes internalized in U87-Luc cells, within an intracellular vesicle, following the treatment described in $\mathbf{a}$. $\mathbf{d}$ Percentage of living cells measured following a treatment in which U87-Luc cells were brought into contact with $700 \mathrm{\mu g} / \mathrm{ml}$ of CM during 24 h and either no exposed to one MS (W/o MS) or exposed to one MS (With 1 MS). The MS consisted in the application of an AMF of $198 \mathrm{kHz}$ and $27 \mathrm{mT}$ during 30 min

$\Delta \mathrm{T}$, which decrease from $\mathrm{SAR}=1234 \pm 307 \mathrm{~W} / \mathrm{g}_{\mathrm{Fe}}$ and $\Delta \mathrm{T}=95 \pm 8^{\circ} \mathrm{C}$ before internalization to $\mathrm{SAR}=57 \pm 11 \mathrm{~W} /$ $\mathrm{g}_{\mathrm{Fe}}$ and $\Delta \mathrm{T}=7.4 \pm 0.7^{\circ} \mathrm{C}$ following internalization, where the latter SAR value was estimated using the formula $\mathrm{SAR}=(\Delta \mathrm{T} / \delta \mathrm{t}) \cdot\left(\mathrm{Cv} / \mathrm{X}_{\mathrm{Fe}}\right)$, where $\mathrm{C}_{\mathrm{v}}=4.2 \mathrm{~J} / \mathrm{gK}, \mathrm{X}_{\mathrm{Fe}}=0.7 \mathrm{mg} /$ $\mathrm{ml}$, and $\Delta \mathrm{T} / \delta \mathrm{t}=9.5 \pm 1.8{ }^{\circ} \mathrm{C} / \mathrm{s}$ (Table 2). Most interestingly, despite this alteration, the application of the magnetic field on magnetosome is accompanied by a decrease in the percentage of living cells from $55 \%$ without MS to $30 \%$ with one MS (Fig. 2d). Although the magnetosome heating power is weakened in vitro, it remains significant and could cause the death of tumor cells. Another reason for the observed cytotoxicity could be endotoxin release that might result from the process of magnetosome degradation inside the cells. Such mechanism is not directly proven here, since endotoxin release would be difficult to monitor inside the cells. Instead, it is suggested based on previous reports describing endotoxins as being able to cause cellular death $[23,24]$.

\section{Magnetosomes administered to intracranial U87-Luc glioblastoma tumors and exposed to 15 sessions} of alternating magnetic field application reduce in sizes and heating power, while keeping efficient anti-tumor activity resulting in full tumor disappearance among $50 \%$ of treated mice

The impact of intra-tumor magnetosome administration on nanoparticle size is examined. For that, slides of 

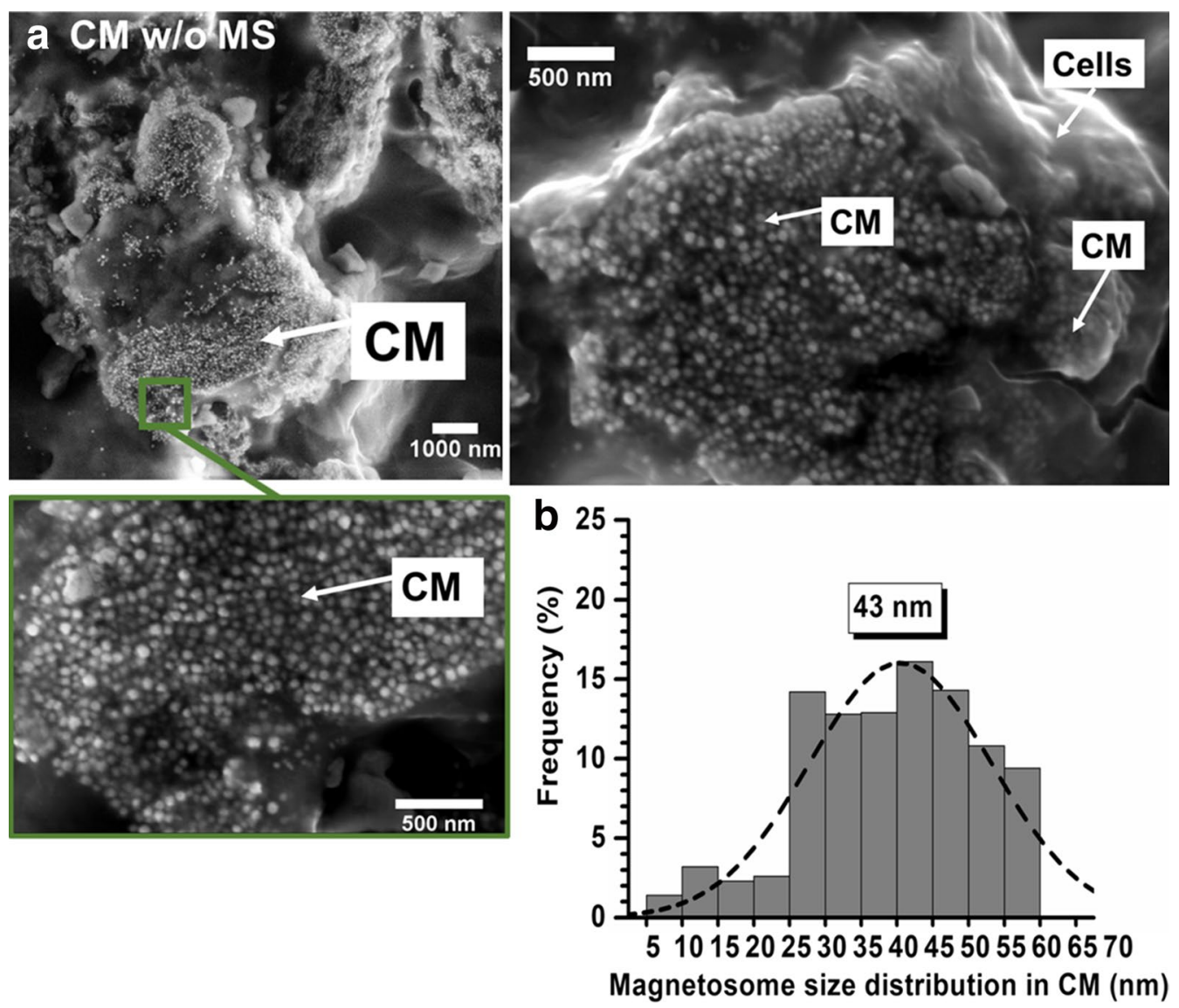

Fig. 3 a Scanning electron microscopy (SEM) images of a brain section collected at D30 from a mouse treated by CM administration, showing co-localization of cells and CM. $\mathbf{b}$ Magnetosome size distribution deduced from $\mathbf{a}$, estimated from the size of 600 magnetosomes

brains of mice bearing U87-Luc tumors treated by CM administration without MS are collected 30 days following $\mathrm{MC}$ administration and analyzed by scanning electron microscopy (SEM). The SEM image of a slide treated in these conditions is presented in Fig. 3a. It shows that magnetosomes are localized in the same region as cells and are characterized by an average size of $\sim 43 \pm 8 \mathrm{~nm}$ (Fig. 3b). Compared with the size distribution of magnetosomes before administration (Fig. 1e), that of Fig. 3b has become mono-modal, the proportion of the largest magnetosomes has increased, i.e. $76.5 \%$ of magnetosomes are larger than $30 \mathrm{~nm}$, whereas the percentage of the smallest ones has decreased, i.e. $23.5 \%$ of magnetosomes are smaller than $30 \mathrm{~nm}$ (Table 1), suggesting that magnetosome intra-tumor administration resulted in a preferential dissolution of the smallest magnetosomes.

To reflect the conditions of magnetic hyperthermia treatment, magnetosomes were then treated by the previously mentioned step of intra-tumor CM administration, which was followed by 15 magnetic sessions of alternating magnetic field application. Slides of mouse brains treated under these conditions were examined by SEM. They reveal the presence of $\mathrm{CM}$ co-localized with cells (Fig. 4a) as in Fig. 3a, but with an average magnetosome size that has decreased down to $\sim 29 \pm 8 \mathrm{~nm}$ (Fig. 4b). Compared with the treatment without MS, that with MS led to a percentage of the smallest magnetosomes that is larger, i.e. $\sim 64 \%$ of magnetosomes are smaller than $30 \mathrm{~nm}$, and to a percentage of the largest magnetosomes that is smaller, i.e. $\sim 36 \%$ of magnetosomes are larger than $30 \mathrm{~nm}$ (Table 1), suggesting more stringent conditions of degradation with than without MS, leading to the partial dissolution of the largest magnetosomes. In addition, while in vitro size-measurements carried out on internalized magnetosomes showed that more than $80 \%$ of magnetosomes are between 1 and $15 \mathrm{~nm}$ (Fig. 2c), the histogram of Fig. $4 \mathrm{~b}$ indicates that this range of magnetosome sizes occurs for less than $5 \%$ of magnetosomes following in vivo treatment, which might suggest that magnetosome alteration is different in vitro and in vivo. 

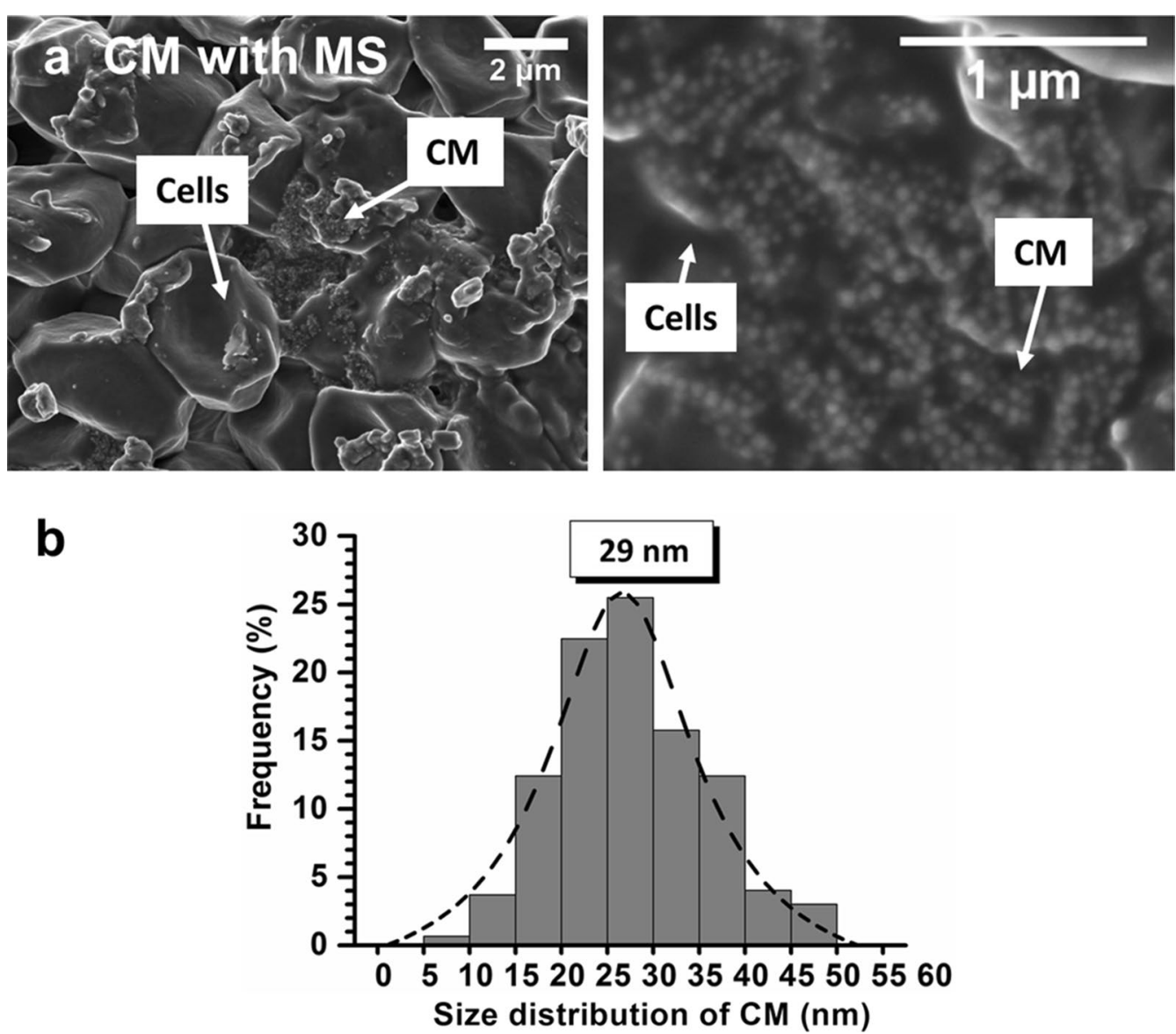

Fig. 4 a Scanning electron microscopy (SEM) images of a brain section collected at D30 from a mouse treated by CM administration followed by 15 MS, where each MS consisted in the application of an AMF of $198 \mathrm{kHz}$ and $27 \mathrm{mT}$ applied during $30 \mathrm{~min}$, showing co-localization of cells and CM. $\mathbf{b}$ Magnetosome size distribution deduced from $\mathbf{a}$, estimated from the size of 600 magnetosomes

Although magnetosome alteration is expected to undermine magnetosome heating power, it does not necessarily deprive magnetosomes of the faculty to destroy the tumor, as previously described during the analysis of the in vitro results. For this reason, we have studied magnetosome in vivo anti-tumor activity by using 60 nude mice, which were divided into 6 different groups of 10 mice each. We first administered $10^{5}$ U87Luc cells inside the brains of these mice at the injection site of (0.2.0) bregma coordinates using a stereotactic helmet. We waited for 1 week that the tumor reached $2 \mathrm{~mm}^{3}$ and started the treatment at D8 (8 days following tumor cell administration at D0). The groups were treated as follows (Additional file 1: Table S3):

- Group 1 received at D8 $2 \mu \mathrm{l}$ of a solution of $5 \%$ of glucose at (0.2.0);

- Group 2 received at D8 $2 \mu \mathrm{l}$ of $5 \%$ of glucose at (0.2.0) followed by 3 MS at D8, D9, and D10;
- Group 3 received at D8 $2 \mu \mathrm{l}$ of $5 \%$ glucose at (0.2.0) followed by 12 MS at D8, D9, D10, D15, D16, D17, D22, D23, D24, D29, D30, D31;

- Group 4 received at D8 $2 \mu \mathrm{l}$ of $40 \mu \mathrm{g}$ of $\mathrm{CM}$ at (0.2.0);

- Group 5 received at D8 $2 \mu \mathrm{l}$ of $40 \mu \mathrm{g}$ of CM at (0.2.0) followed by $3 \mathrm{MS}$ at D8, D9, D10;

- Group 6 received at D8 $2 \mu \mathrm{l}$ of $40 \mu \mathrm{g}$ of CM at (0.2.0) followed by $15 \mathrm{MS}$ at D8, D9, D10, D15, D16, D17, D22, D23, D24, D29, D30, D31, D36, D37, D38;

Each MS consisted in the application of an AMF of average strength $27 \mathrm{mT}$ and frequency $198 \mathrm{kHz}$ during 30 min. During the course of each MS, the temperature of the mouse brain was monitored with an infra-red camera. The size of the tumor, which was shown to be proportional to the tumor bioluminescence intensity BLI [25], was followed by measuring the BLI of the mouse brains in-between the various MS. 
We have measured tumor temperature increases during the various MS of group 6 treated by $\mathrm{CM}$ administration followed by $15 \mathrm{MS}$. During the first $5 \mathrm{MS}$, the tumor temperature increased by $4 \pm 1{ }^{\circ} \mathrm{C}(\mathrm{MS} 1), 1.7 \pm 1{ }^{\circ} \mathrm{C}$ (MS2), $0.4 \pm 0.4{ }^{\circ} \mathrm{C}$ (MS3 to MS5), resulting in SAR of $4.7 \pm 1.5 \mathrm{~W} /$ gFe (MS1), $2.5 \pm 1 \mathrm{~W} / \mathrm{gFe}$ (MS2), $2 \times 10^{-3} \pm 10^{-4} \mathrm{~W} / \mathrm{gFe}$ (MS3 to MS5), where the SAR is measured using the formula $\mathrm{SAR}=(\Delta \mathrm{T} / \delta \mathrm{t}) \cdot\left(\mathrm{C}_{\mathrm{v}} / \mathrm{X}_{\mathrm{Fe}}\right)$, where $\mathrm{Cv}=4.2 \mathrm{~J} / \mathrm{gK}$ is the specific heat capacity of water, $\mathrm{X}_{\mathrm{Fe}}=0.02 \mathrm{~g} / \mathrm{ml}$ is the nanoparticle concentration in iron, $(\Delta \mathrm{T} / \delta \mathrm{t})$ is the initial slope of the temperature variation with time deduced from Fig. $5 \mathrm{a}$ as $\Delta \mathrm{T} / \delta \mathrm{t}=2.2 \times 10^{-2} \pm 7.1 \times 10^{-3}{ }^{\circ} \mathrm{C} / \mathrm{s}$ (MS1), $\Delta \mathrm{T} / \delta \mathrm{t}=1.1 \times 1$ $0^{-2} \pm 4.4 \times 10^{-3}{ }^{\circ} \mathrm{C} / \mathrm{s}$ (MS2), $\Delta \mathrm{T} / \delta \mathrm{t}=1.1 \times 10^{-5} \pm 5.5 \times 10$

$-7{ }^{\circ} \mathrm{C} / \mathrm{s}$ (MS3 to MS5). Compared with the SAR measured in solution for $40 \mu \mathrm{g}$ of $\mathrm{CM}$ suspended in $2 \mu \mathrm{l}$ of water $\left(\mathrm{SAR}=57 \pm 6 \mathrm{~W} / \mathrm{g}_{\mathrm{Fe}}\right)$, the SAR measured in vivo is lower during the different sessions, which could be explained on the one hand by the diffusion of magnetosomes outside the injection volume and on the other hand by the loss of the Brownian contribution to the heating mechanism, due to a weaker magnetosome movement in tissue than in water. Furthermore, the decrease of the magnetosome heating power between MS1 and MS5, which is followed by a nonmeasurable heating of the tumor between MS6 and MS15, could come from the decrease of magnetosome sizes following the various MS, as highlighted by the SEM analyses of magnetosomes administered to U87-Luc tumors and exposed to 15 MS (Fig. 4b).
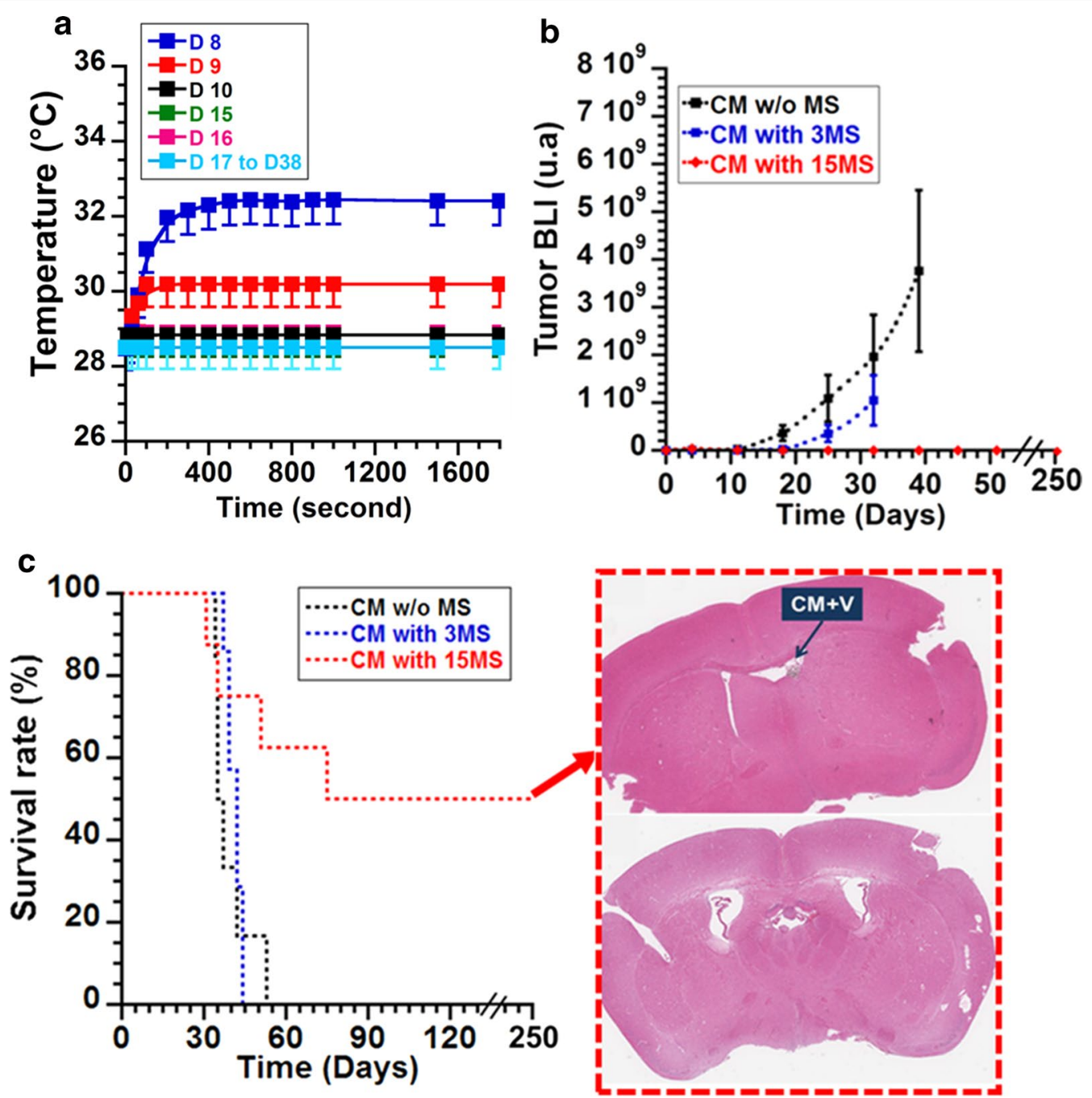

Fig. 5 For a mouse having received CM followed by $15 \mathrm{MS}$, temperature variation measured with an infra-red camera during the course of each MS (a). For mice having received CM without MS or CM followed by 3 or 15 MS, variation of tumor BLI (b), survival rate (c), during the days following tumor cell implantation. The inset of $\mathbf{c}$ shows two representative histological images of brain slides of a mouse euthanized 250 days following tumor cell implantation. Both slides show an absence of tumor. One image shows the presence of CM while the other one lacks CM. CM + V designates chains of magnetosomes in ventricles 
We have then examined the effect of the treatment on anti-tumor activity when magnetosomes were altered following intra-tumor administration and the various MS. In control groups, which received glucose with/without MS (groups 1,2,3), or CM without MS (groups 4), tumor BLI increased exponentially from 0 at D0 to $1-710^{9}$ at D35 (Additional file 1: Figure S2a), the temperature of the mouse brain remained constant at $29{ }^{\circ} \mathrm{C}$ during the course of each MS (Additional file 1: Figure S2b), and anti-tumor activity did not take place. Mice belonging to these groups were euthanized at D37 to D44 (Additional file 1: Figure S2c), when the tumor bioluminescence intensity exceeded $9 \times 10^{9}$. By contrast, when mice belonging to group 5 were injected with CM followed by $3 \mathrm{MS}$, it resulted in partial anti-tumor activity, as highlighted by the behavior of the BLI averaged over all mice that increased more slowly in group 5 than in group 4 (Fig. 5b) and by the BLI of a typical mouse belonging to group 5 that decreases between D11 and D18 (Fig. 6a). In this mouse, such activity is insufficient to prevent tumor re-growth after D18, and the tumor BLI exponentially increases between D18 and D25, as observed in the inset of Fig. 6a. Mice of group 5 needed to be euthanized at D42 (Fig. 5c), without an improvement of the median survival day compared with control group 4 (Fig. 5c). In order to further enhance therapeutic activity, mice belonging to group 6 were injected with CM and exposed

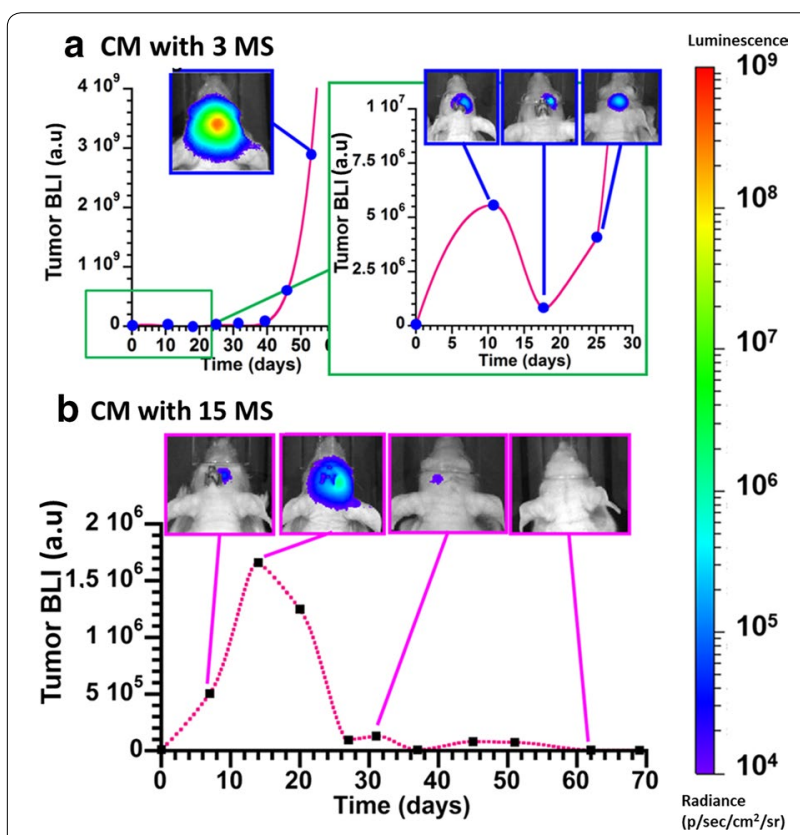

Fig. 6 For two mice having received CM followed by 3 MS (a), or 15 MS (b), variation of tumor BLI as a function of time (days) following tumor cell implantation. The insets of $\mathbf{a}$ and $\mathbf{b}$ show optical images of the brains with an indication of brain BLI to an additional $12 \mathrm{MS}$ as compared with group 5. Under these conditions, the improvement of therapeutic activity is revealed firstly by the BLI averaged over all mice that does not increase between D0 and D250 (Fig. 5b), secondly by the BLI of a mouse of group 6, which continuously decreases between D12 (after 3 MS) and D38 (after $15 \mathrm{MS}$ ) and remains almost undetectable after D38 (Fig. 6b), thirdly by the full tumor disappearance in $50 \%$ of mice belonging to this group, which are still alive at D250 (Fig. 5c), and fourthly by a mouse median survival day (MSD) above D250, which is much larger than the MSD of D36 to D42 estimated for the other groups (Additional file 1: Table S3). Furthermore, mice, which were still alive at D250, were euthanized for histological analysis. Optical micrographs of two representative brain sections of these mice are presented in Fig. 5c, showing either some remains of magnetosomes or no sign of these nanoparticles. They were further characterized by an absence of tumor cells, lesion and oedema, supporting the idea that the treatment leads to full tumor disappearance without inducing severe side effects. We conclude that although the tumor temperature stops increasing following the fifth MS (Fig. 5a) and magnetosome sizes are significantly reduced during the course of the various treatments (Figs. 3 and 4), anti-tumor activity remains persistent.

\section{Possible mechanisms explaining anti-tumor efficacy under conditions of weakened nanoparticle heating power and nanoparticle size reduction}

Figure 7 summarizes the different anti-tumor mechanisms that could occur under conditions of no/moderate heating:

- An immune reaction against the tumor that could be due to endotoxins being released from the magnetosomes following AMF applications, as partly highlighted elsewhere by showing the presence of poly-nuclear neutrophils (PNN) in the magnetosome region following one or three MS [16], without however showing the direct involvement of PNN in the anti-tumor activity, this topic remaining a matter of controversy and open discussions [26, 27],

- Magnetosome internalization, which could favor intracellular heating or release of free iron, e.g. following capture of the magnetosomes by lysosomes as reported elsewhere, [28], hence resulting in an enhanced toxicity towards tumor cells.

- A tumor cell death mechanism dominated by apoptosis, given that apoptosis is known to occur more frequently than necrosis when cells are prone to moderate stresses and/or mild temperature increases [29]. 


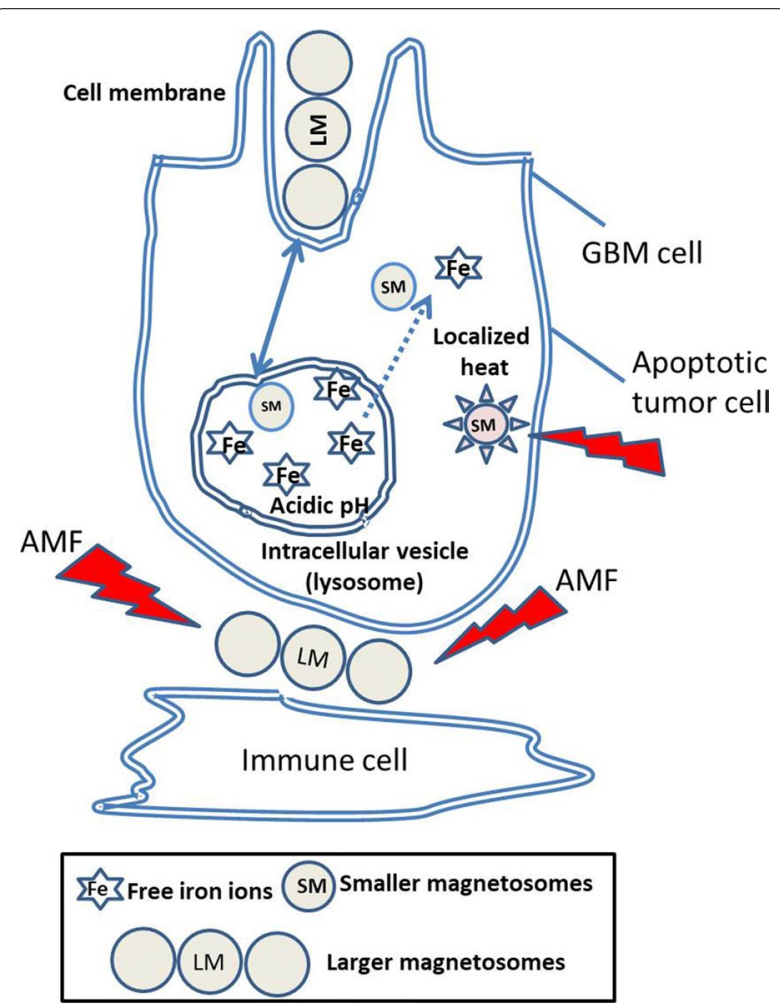

Fig. 7 Suggested mechanisms of tumor cell destruction by magnetosomes exposed to an alternating magnetic field, involving: (i) magnetosome cellular internalization, (ii) localized heat production, (iii) apoptosis of tumor cells, and (iv) attraction of immune cells that could act against the tumor

\section{Experimental section}

Preparation of magnetosomes

To synthetize CM, we purchased Magnetospirillum magneticum strain AMB-1 magnetotactic bacteria from the ATCC $(700,264) .4 \times 10^{7}$ of these bacteria were introduced into one litter of sterile 1653 ATCC culture medium. The media containing the bacteria were then placed in an incubator at $30{ }^{\circ} \mathrm{C}$ for 7 days to enable bacterial growth and magnetosome production. After 7 days, the media were centrifuged at $4000 \mathrm{~g}$ for $45 \mathrm{~min}$. The bacterial pellet was washed using $1 \mathrm{ml}$ of sterile water. Magnetotactic bacteria were concentrated using a strong Neodymium magnet (0.6 Tesla), re-suspended in $0.05 \mathrm{M}$ TRIS and sonicated continuously with finger at $0{ }^{\circ} \mathrm{C}$ during $2 \mathrm{~h}$ at $30 \mathrm{~W}$. The suspension of magnetosomes was washed several times with sterile water using a magnet to isolate magnetosome chains from the supernatant containing cellular debris and residual bacteria until cellular debris have disappeared from the supernate. Between each wash, sonication was carried out at $30 \mathrm{~W}$ by a series of three pulses of $2 \mathrm{~s}$. Magnetosome chains were then re-suspended in $1 \mathrm{ml}$ of sterile water. For intracranial injections, magnetosome chains were re-suspended in a sterile injectable solution containing $5 \%$ of glucose and exposed to irradiation of a UV lamp (UV) for $12 \mathrm{~h}$ for partial sterilization.

\section{TEM}

To determine nanoparticle sizes, shapes, and organization, $7 \mu \mathrm{l}$ of nanoparticle suspension were deposited on top of a carbon grid, left to dry, and then nanoparticles were then imaged using a transmission electron microscope (JEM-2100, JEOL, Japan). To obtain TEM micrographs of assemblies of cells and nanoparticles, we prepared the samples in the following manner: (i), removal of culture medium from the sample containing U87 cells incubated with magnetosomes for $24 \mathrm{~h}$, (ii) washing of cells with $0.2 \mathrm{M}$ sodium cacodylate buffer, (iii) fixing cells for $1 \mathrm{~h}$ at room temperature with $2.5 \%$ glutaraldehyde in $0.2 \mathrm{M}$ sodium cacodylate buffer, (iv) washing two times the cells with $0.2 \mathrm{M}$ cacodylate buffer, (v) storing the cells at $4{ }^{\circ} \mathrm{C}$, (vi) post-fixing of cells with osmium tetraoxide $1 \%$ and passing cells through uranyl acetate, (vii) dehydrating cells in an ethanol series (30$100 \%$ ), (viii) embedding cells in epoxy medium (EPON 812; Shell Chemical, San Francisco, California), (ix) cutting in thin sections with a microtome. Ultrathin Sections $(80 \mathrm{~nm})$ were stained by lead citrate and were examined by using a ZEISS EM902 TEM operated at $80 \mathrm{kV}$ (Carl Zeiss-France, MIMA2 Microscopy Platform, UR1196, INRA, Jouy en Josas, France). Images were acquired with a charge-coupled device camera (Megaview III) and analyzed with ITEM Software (Eloïse, France).

\section{Materials and method \\ ICP-AES}

Iron concentrations of the samples was then determined using ICP-AES measurements (ICP-AES ICAP6200 ThermoScienbtific). A natural abundance iron standard solution was analyzed during sample runs in order to account for charges in the systematic bias. The calibration curve was obtained using four iron standard solutions (Sigma-Aldrich) in the range $0.1-0.05 \mathrm{ug} / \mathrm{ml}$.

\section{Nanoparticle characterization by absorption, CHNS, FTIR, DLS, magnetic measurements}

The stability of nanoparticles in suspension was estimated by measuring the variation of the optical density of nanoparticle suspensions at $1 \mathrm{mg} / \mathrm{ml}$ in iron, measured at $480 \mathrm{~nm}$, within $15 \mathrm{~min}$ following the homogenization of the suspension. Zeta potential of the different nanoparticles in suspension was measured by Dynamic light scattering, DLS (ZEN 3600, Malvern Instruments, UK) 
using a suspension of $100 \mu \mathrm{g} / \mathrm{ml}$ in iron whose $\mathrm{pH}$ was adjusted between a $\mathrm{pH} 2$ and 12 by using $\mathrm{HCl}$ and $\mathrm{NaOH}$ solutions. Nanoparticle FTIR spectra were recorded with a FTIR spectrometer (Vertex 70, Bruker, USA) on lyophilized nanoparticles suspensions mixed with $\mathrm{KBr}$. The percentage in mass of organic material at nanoparticle surface was estimated using an elemental CHNS analyzer (Flash EA 1112, Thermo Fisher Scientific, USA). Magnetic properties of the nanoparticles were determined by measuring nanoparticle magnetization curves at room temperature between -1 and $+1 \mathrm{~T}$, using a vibrating sample magnetometer (VSM3900, Princeton Measurements Corporation, USA).

\section{Measurement of the quantity of endotoxins contained in nanoparticle suspensions without magnetic excitation} The endotoxin concentration of $25 \mu$ l suspensions containing $0.4 \mathrm{mg} / \mathrm{ml}$ in iron of nanoparticles, designated as $\mathrm{Q}_{\mathrm{BMS}}$, was measured with the LAL assay. The latter was carried out under sterile conditions using the 88282 ThermoScientific kit called "Pierce LAL Chromogenic Endotoxin Quantitation Kit". We used a low nanoparticle concentration $(0.4 \mathrm{mg} / \mathrm{ml})$ to avoid interference between the nanoparticles and the LAL assay.

\section{Measurement of the percentage of endotoxins released by nanoparticles in suspension following magnetic excitation}

$2 \mu \mathrm{l}$ of suspensions containing $40 \mu \mathrm{g}$ in iron of nanoparticles were introduced at the bottom of a small caliper mimicking in vivo conditions and exposed (or not) to $1 \mathrm{MS}$, during which an AMF of $198 \mathrm{kHz}$ and average strength $27 \mathrm{mT}$ was applied during $30 \mathrm{~min}$. The supernate was then isolated from the nanoparticles by centrifugation at $14,000 \mathrm{~g}$ during $10 \mathrm{~min}$ and its endotoxin concentration was measured using the LAL assay, as described above. The percentage of endotoxins released corresponded to the ratio $\mathrm{Q}_{\mathrm{AMS}} / \mathrm{Q}_{\mathrm{BMS}}$ between the quantity of endotoxins in the supernate following one MS, $\mathrm{Q}_{\mathrm{AMS}}$, and the quantity of endotoxins measured in the nanoparticle suspension before magnetic session, $\mathrm{Q}_{\mathrm{BMS}}$.

\section{Determination of the nanoparticle specific absorption rate (SAR)}

The variations of temperatures as a function of time were measured in the various treatments, during which nanoparticles in suspension, in contact with cells or in tumor brain were exposed to the AMF. The specific absorption rate was measured using the relation: $\mathrm{SAR}=(\Delta \mathrm{T} / \delta \mathrm{t}) \cdot\left(\mathrm{C}_{\mathrm{v}} /\right.$ $\mathrm{X}_{\mathrm{Fe}}$ ), where $\mathrm{C}_{\mathrm{v}}=4.2 \mathrm{~J} / \mathrm{gK}$ is the specific heat capacity of water, $\mathrm{X}_{\mathrm{Fe}}$ is the nanoparticle concentration in iron expressed in $\mathrm{g} / \mathrm{mL},(\Delta \mathrm{T} / \delta \mathrm{t})$ is the initial temperature variation with time expressed in $\mathrm{K} / \mathrm{s}$.

\section{Cell cultivation}

Human GBM cell lines (U87-MG Luc) transduced with a Luciferase gene were cultivated in Dulbecco's Modified Eagle Medium (DMEM) containing 10\% fetal bovine serum (FBS) at $37{ }^{\circ} \mathrm{C}$ in the presence of $5 \% \mathrm{CO}_{2}$. After reaching confluence, culture medium was removed using Hank's Balanced Salt Solution (HBSS). Following trypsinization at $37{ }^{\circ} \mathrm{C}$ during $5 \mathrm{~min}$, cells were detached, FBS was then added to stop the action of trypsin, and cellular concentration was measured using a Malassez counting cell.

\section{In vitro treatment of cells}

$5 \times 10^{5}$ U87-Luc cells were seeded at the bottom of Petri dishes of $35 \mathrm{~mm}$ diameter for $24 \mathrm{~h}$. Nanoparticles of concentration in iron of $700 \mu \mathrm{g} / \mathrm{ml}$ were added (or not) and exposed (or not) to on MS, during which an AMF of $27 \mathrm{mT}$ and $198 \mathrm{kHz}$ was applied for $30 \mathrm{~min}$. The treated assemblies of cells and nanoparticles, hence obtained, were incubated at $37{ }^{\circ} \mathrm{C}$ for an additional day. The medium containing (or not) nanoparticles was then removed and the cells were washed twice with cold PBS. Following the in vitro treatment, the percentages of living and apoptotic cells were measured using the FITC Annexin V/Dead Cell Apoptosis Kit (ThermoFisher scientific, reference: V13242). For that, $10 \mu \mathrm{l}$ of the washed cells were loaded into the sample slide and were inserted completely into a Countess ${ }^{\mathrm{TM}}$ II FL Automated Cell Counter (Thermo Fisher scientific, reference: 15307812), which was able to detect Annexin and Propidium Iodide fluorescence emission. Following the in vitro treatments, the number of cells in the assemblies was counted by a Countess $^{\mathrm{TM}}$ II FL Automated Cell Counter. Assemblies of washed cells were centrifuged, the supernatant was removed and replaced by $286 \mu \mathrm{l}$ of $\mathrm{HNO}_{3}$ (70\%). The treated assemblies were kept at $4{ }^{\circ} \mathrm{C}$ during $24 \mathrm{~h}$ to lyse cells and dissolve nanoparticles into free iron. Finally, $10 \mathrm{ml}$ of filtered water were added to all treated mixtures and iron concentration was then determined using ICP-AES measurements. We deduced the average quantity of iron coming from the magnetosomes, which was internalized in each cell, using the following formula: Iron internalization $(\%)=100^{*}\left(\mathrm{Q} / \mathrm{Q}^{\circ}\right)$, where $\mathrm{Q}$ and $\mathrm{Q}^{\circ}$ correspond to the quantity of iron internalized per cells after and before treatment, respectively. After in vitro treatment described above, cells were also stained with Prussian blue, and observed under optical microscope to examine the presence of iron, which appeared in blue color.

\section{In vivo mouse treatments}

The in vivo protocol was approved by the local animal ethics committee of the University Pierre-et-Marie-Curie 
(Paris, France). 6 weeks old CD-1 female nude mice of average weight $20 \mathrm{~g}$ were purchased from Charles River. All mice were treated and kept in an environment complying with ethical guidelines and surgery was carried out following the guidelines of the Institutional Animal Care and Use Committee ("Ethic committee Charles Darwin $\left.\mathrm{N}^{\circ} 5^{\prime \prime}\right)$. Mice were fed and watered according to these guidelines and we used cervical dislocation to euthanize them when their weight had decreased by more than $20 \%$ or when signs of pain, unusual posture or prostration were observed. Mice were divided in 6 groups of 10 mice each treated as shown in Additional file 1: Table S2. For the various treatments, the mice were anesthetized with a mixture of Ketamine $(100 \mathrm{mg} / \mathrm{kg})$ and Xylazine $(8 \mathrm{mg} /$ $\mathrm{kg}$ ) in isotonic solution $(0.9 \%$ of $\mathrm{NaCl})$. To administer the tumor cells at D-8 and the various administrations at D0 (glucose, IONP, CM), a surgical procedure was carried out. For that, the mouse heads were fixed in a stereotactic frame, a craniotomy was realized at coordinates (0.2.0) $\mathrm{mm}$ and the cell suspension or various treatments (glucose, IONP, CM) were administered at (0.2.2.) $\mathrm{mm}$. To follow tumor size evolution, Bioluminescence intensity (BLI) emitted by living tumor cells was measured during the day preceding or following MS (one a weak). We estimated that BLI maximum signal was reached 10 min following luciferin administration and we therefore measured BLI at that time in each mouse. A relation between tumor volume and tumor BLI was established by measuring histologically tumor volumes in a series of mice euthanized at different days following tumor cell implantation and tumor BLI in living mice at the same days as those of the euthanasia [29]. The spatial temperature distribution in the tumor was recorded during each MS with an infrared camera (EasIRTM-2, Optophase) positioned $20 \mathrm{~cm}$ above the coil generating the AMF. We verified that the maximum temperature measured with the infrared camera was the same as that of the temperature measured with a thermocouple microprobe (IT-18, Physitemp, Clifton, USA) positioned at tumor center and we plotted the maximum temperature as a function of time during each MS. Mouse body weights were measured every day and mice were euthanized when losses in mouse body weights exceeded $20 \%$. Mice, which were still alive at D242, were euthanized and brain sections were collected for further histological examination by the hematoxylin and eosin (H\&E) staining to determine if the tumor had fully disappeared. Mouse survival times were plotted according to the Kaplan-Meier method [26]. Statistical significance of survival time between the different groups was evaluated using the log rank test. Parameters were expressed as median and p-values, relative to control group.

\section{Scanning electron microscopy (SEM) analysis of slides of mouse brains}

Mouse brains were washed with $10 \%$ of sucrose, embedded in OTC (TissueTek), and kept at $-80{ }^{\circ} \mathrm{C}$ in bath of isopentane cooled by liquid nitrogen. Frozen sections of their brains were obtained by cryocut $(10 \mu \mathrm{m})$, deposited on a stub, covered by a carbon layer and analyzed by scanning electron microscope (SEM-FEG Zeiss Ultra55). We obtained surface images of cells with nanoparticles from which we could measure magnetosome sizes.

\section{Conclusion}

Cancer nano-therapies have raised a surge of interest in the medical field due to their potential larger benefit to risk ratio compared with more conventional treatments. To achieve optimal treatment outcome, nanoparticle distribution needs to be precisely controlled. On the one hand, nanoparticles should be degraded to enable their elimination by the organism. On the other hand, such alteration should not prevent persistent anti-tumor activity until full tumor disappearance. Here, we have chosen to study a certain type of nanoparticles, called magnetosome which are synthesized by magnetotactic bacteria, and possess a well-balanced size-distribution, i.e. with $58 \%$ of magnetosomes larger than $30 \mathrm{~nm}$ and $42 \%$ of them smaller than $30 \mathrm{~nm}$ (Table 1). This property enables a distinction to be made between conditions affecting the size of small and large nanoparticles and furthermore to study the impact of size variation on nanoparticle heating power. In addition, magnetosomes studied here are extracted from magnetotactic bacteria and consist of a ferrimagnetic iron oxide mineral core surrounded by a layer containing endotoxins, allowing endotoxin release under conditions of nanoparticle size variation. To take into consideration the diversity of altering conditions that can be encountered during a real in vivo treatment, we have chosen to treat magnetosomes in different ways, i.e., by internalizing them in U87-Luc tumor cells (first treatment), by administering them in intracranial U87Luc tumors without (second treatment) or with (third treatment) 15 magnetic sessions of alternating magnetic field application. Whereas the second treatment corresponds to mild conditions of degradation, i.e. it results in the dissolution of the smallest magnetosomes yielding $76 \%$ of magnetosomes larger than $30 \mathrm{~nm}$ and $24 \%$ of them smaller than $30 \mathrm{~nm}$ (Table 1), the first and third treatments lead to a more stringent degradation, which is associated with the dissolution of the largest magnetosomes and therefore with a larger percentage of the smallest than largest magnetosomes, i.e. $64-92 \%$ of magnetosomes are below $30 \mathrm{~nm}$ while $8-36 \%$ of them are above $30 \mathrm{~nm}$ (Table 1). The most interesting result 
highlighted in this study relies on the observation that despite magnetosome alteration observed in vitro and in vivo and the loss of magnetosome heating power that it induces, i.e. SAR and $\Delta \mathrm{T}$ decrease partly in vitro by 95\% between before and after magnetosome internalization in U87-Cells or fully in vivo to reach $S A R=0 \mathrm{~W} / \mathrm{g}_{\mathrm{Fe}}$ and $\Delta \mathrm{T}=0{ }^{\circ} \mathrm{C}$ after the sixth magnetic session, magnetosomes are able to maintain their anti-tumor efficacy. Indeed, on the one hand, the percentage of living cells decreases from 55 to $30 \%$ between before and after the application of one MS on internalized magnetosomes and one the other hand intracranial U87-Luc tumors injected with CM followed by 15 magnetic sessions fully disappear among $50 \%$ of treated mice.

The results presented here are important in the field of nanomedicine, since they show that nanoparticulate systems can maintain anti-tumor activity after their degradation in vivo. To the author's knowledge, whereas such type of behavior is desired to reach a sustained and long-term anti-tumor activity in the tumor environment, which is known to be degrading, it has not yet been reported.

\section{Supplementary information}

Supplementary information accompanies this paper at https://doi. org/10.1186/s12951-019-0555-2.

Additional file 1. Figure S1. (a), \% of carbon in a suspension of magnetosomes as measured with a CHNS. (b), Hysteresis curve of a dried suspension of magnetosomes. (c), variation of zeta potential of a suspension of magnetosomes between $\mathrm{pH} 2$ and $\mathrm{pH}$ 12. (d), Heating curve of a suspension of magnetosomes ( 2 mg of magnetosomes in 100 $\mu \mathrm{l}$ of water) exposed to an AMF of $27 \mathrm{mT}$ and $198 \mathrm{kHz}$ during 600 seconds. Figure S2. For mice having received glucose without MS, or with 3 or 15 MS, variations of tumor BLI as a function of time (days) following tumor cell implantation, (a), temperature variation measured during each MS, (b), survival rate during the days following tumor cell implantation, (c). Table S1. Properties of untreated magnetosomes. Table S2. Treatment conditions of the different groups of mice. Table S3. Median survival day and associated p-value estimated for the different groups of treated mice.

\section{Abbreviations}

AMF: alternating magnetic field; Magnetic hyperthermia: the application of an alternating magnetic field to an assembly of nanoparticles, often resulting in the production of heat; MS: a magnetic session during which magnetic hyperthermia is carried out; CM: chains of magnetosomes extracted from magnetotactic bacteria.

\section{Acknowledgments}

We thank the platform 'Histim' of the Cochin Institute for their help concerning histological experiments and for frozen tissues preparation. We thank S. Morosan, O. Bregerie, B. Kane and A. Jacquet for their help concerning in vivo imaging and animals healthy. We also thank Laure Cordier for their help concerning ICP measurement, this work was supported by the IPGP multidisciplinary program PARI and by Région Ile-de-France SESAME Grant No. 12015908.

\section{Authors' contributions}

EA wrote the manuscript and directed the research presented in this study. IC carried out the in vivo and in vitro experiments. FG and her master student (Fiorenza Coragliotti) led the TEM internalization study. JYD, Al, CS helped to set-up the in vivo mouse experiments. CA participated in the histological analysis of the tissues. FG carried out the SEM and TEM experiments and brought his general scientific view on the project. All authors read and approved the final manuscript.

\section{Funding}

We would like to thank the Eurostars program (Nanoneck-2, E9309), subvention AIR from the region of Paris (A1401025Q), the ANRT, the ANR (Méfisto project), the French Research Tax Credit Program, Paris Biotech Santé, BPI, the University Paris 6, the University Paris XI, Marianne Labussière and Elvis Dervis, as well as all other people and structures in France and Europe that have helped us and that have been supportive and enthusiastic about our research activities.

\section{Availability of data and materials}

Please contact author for data requests.

\section{Ethics approval and consent to participate}

Not applicable.

\section{Consent for publication}

Not applicable.

\section{Competing interests}

Edouard Alphandéry and Imène Chebbi have been working in the start-up Nanobacterie.

\section{Author details}

${ }^{1}$ Institut de minéralogie et de Physique Des matériaux et de Cosmochimie, UMR 7590 CNRS, Sorbonne Universités, UPMC, University Paris 06, Muséum National D'Histoire Naturelle, 4 Place Jussieu, 75005 Paris, France. ${ }^{2}$ Nanobacterie SARL, 36 boulevard Flandrin, 75016 Paris, France. ${ }^{3}$ Sorbonne Université, Inserm, CNRS, UMR S 1127, Institut du Cerveau et de la Moelle épinière, ICM, AP-HP, Hôpitaux Universitaires La Pitié Salpêtrière - Charles Foix, Service de Neurologie 2-Mazarin, F-75013 Paris, France. ${ }^{4}$ Laboratoire de Neuropathologie, GHU Paris-Sud-Hôpital Bicêtre, 78 rue du Général Leclerc, 94270 Le Kremlin Bicêtre, France. ${ }^{5}$ Laboratoire de matière et systèmes Complexes, MSC, Université Paris Diderot, Bâtiment Condorcet, Case 7056, 75205 Paris Cedex 13, France. ${ }^{6}$ Institut Universitaire de France, 75013 Paris, France.

Received: 21 September 2019 Accepted: 3 December 2019 Published online: 23 December 2019

\section{References}

1. Kennedy JE. High-intensity focused ultrasound in the treatment of solid tumors. Nat Rev Cancer. 2005;5:321-7.

2. Thako AS, Gambhir SS. Nanooncology: the future of cancer diagnosis and therapy. CA Cancer J Clin. 2013;63:395-418.

3. Alphandéry E, Grand-Dewyse P, Le Fèvre R, Mandawala C, Durand-Dubief M. Cancer therapy using nanoformulated substances: scientific, regulatory and financial aspects. Exp Rev Cancer Ther. 2015;15:1233-55.

4. Maier-Hoff K, Rothe R, Scholz R, Van den Bent MJ, Taphoorn MJ, Janzer RC, Ludwin SK, Allgeier A, Fisher B, Belanger K, Hau P, Brandes AA, Gijtenbeek J, Marosi C, Vecht CJ, Mokhtari K, Wesseling P, Villa S, Eisenhauer E, Gorlia T, Weller M, Lacombe D, Cairncross JG, Mirimanoff RO. Intracranial thermotherapy using magnetic nanoparticles combined with external beam radiotherapy: Results of a feasibility study on patients with glioblastoma multiforme. J. Neuro-Oncol. 2007;81:53-60.

5. Maier-Hoff K, Ulrich F, Nestler D, Niehoff H, Wust P, Tiesen B, Orawa H, Budach V, Jordan A. Efficacy and safety of intratumoral thermotherapy using magnetic iron-oxide nanoparticles combined with external beam radiotherapy on patients with recurrent glioblastoma multiforme. J. Neuro-Oncol. 2011;103:317-24.

6. Binnemars-Postma KA, Ten Hoopen HW, Storm G, Prakash J. Differential uptake of nanoparticles by human M1 and M2 polarized macrophages: protein corona as a critical determinant. Nanomedicine. 2016;11:2889-902.

7. Sosale NG, Spinler KR, Alvey C, Disher DE. Macrophage engulfment of a cell or nanoparticle is regulated by unavoidable opsonization, a 
species-specific 'Marker of Self' CD47, and target physical properties. Curr Opin Immunol. 2015;35:107-12.

8. Di Corato R, Espinosa A, Lartigue L, Tharaud M, Chat S, Pellegrino T, Ménager C, Gazeau F, Wilhelm C. Magnetic hyperthermia efficiency in the cellular environment for different nanoparticle designs. Biomaterials. 2014;35:6400-11.

9. Alphandéry E, Faure S, Raison L, Duguet E, Howse PA, Bazylinski DA. Heat production by bacterial magnetosomes exposed to an oscillating magnetic field. J Phys Chem C. 2011;115:18-22.

10. Alphandéry E, Amor M, Guyot F, Chebbi I. The effect of iron-chelating agents on Magnetospirillum magneticum strain AMB-1: stimulated growth and magnetosome production and improved magnetosome heating properties. Appl MicriolBiotechnol. 2012;96:663-70.

11. Alphandéry E, Lijeour L, Lalatonne Y, Motte L. Different signatures between chemically and biologically synthesized nanoparticles in a magnetic sensor: a new technology for multiparametric detection. Sens Actuators B Chem. 2010;147:786-90.

12. Bazylinski DA, Frankel RB. Magnetosome formation in prokaryotes. Nat Rev Microbiol. 2004;2:217-30.

13. Faivre D, Schüler D. Magnetotactic bacteria and magnetosomes. Chem Rev. 2008;108:4875-98.

14. Alphandéry E, Chebbi I, Guyot F, Durand-Dubief M. Use of bacterial magnetosomes in the magnetic hyperthermia treatment of tumors: a review. Int J Hyperthermia. 2013;29:801-9.

15. Alphandéry E, Faure S, Seksek O, Guyot F, Chebbi I. Chains of Magnetosomes extracted from AMB-1 magnetotactic bacteria for application in alternative magnetic field cancer therapy. ACS Nano. 2011;5:6279-96.

16. Alphandéry E, Idbaih A, Adam C, Delattre JY, Schmitt C, Guyot F, Chebbi I. Chains of magnetosomes with controlled endotoxin release and partial tumor accupation induce full destruction of intracranial U87-Luc glioma in mice uner the application of an alternating magnetic field. J Control Released. 2017;262:259-72.

17. Le Fèvre R, Durand-Dubief M, Chebbi I, Mandawala C, Lagroix F, Valet JP, Idbaih A, Adam C, Delattre JY, Schmitt C, Maake C, Guyot F, Alphandéry E. Enhanced antitumor efficacy of biocompatible magnetosomes for the magnetic hyperthermia treatment of glioblastoma. Theranostics. 2017;7:4618-31.

18. Predoi D, Andronescu E, Radu M, Munteanu MC, Dinischiotu A. Synthesis and characterization of bio-compatible maghemite nanoparticles. Digest J Nanomater Biostruct. 2010;5:779-86.

19. Xie J, Chen K, Chen X. Production, modifi cation and bio-applications of magnetic nanoparticles gestated by magnetotactic bacteria. Nano Res. 2009;2:261-78.
20. Abramson MB, Norton WT, Katzman R. Study of ionic structures in phospholipids by infrared spectra. J Biol Chem. 1965;240:2389-95.

21. Yoshino T, Hirabe H, Takahashi M, Kuhara M, Takeyama H, Matsunaga T. Magnetic cell separation using nano-sized bacterial magnetic particles with reconstructed magnetosome membrane. Biotechnol Bioeng. 2008;101:470-7.

22. Alphandéry E, Guyot F, Chebbi I. Preparation of chains of magnetosomes, isolated from Magnetospirillum magneticum strain AMB-1 magnetotactic bacteria, yielding efficient treatment of tumors using magnetic hyperthermia. Int J Pharma. 2012;434:444-52.

23. Nalbantsoy A, Karabay-Yavasoglu NU, Deliloglu-Gurhan I. Determination of in vivo toxicity and in vitro cytotoxicity of lipopolysaccharide isolated from Salmonellaenteritidis and its potential use for production of polyclonal antibody. Food Agric Immunol. 2011;22:271-81.

24. Vogel SN, Marshall ST, Rosenstreich DL. Analysis of the effects of lipopolysaccharide on macrophages: differential phagocytic responses of $\mathrm{C3H} /$ HeN and C3H/HeJ macrophages in vitro. Infect Immun. 1979;25:328-36.

25. Alphandéry E, Idbaih A, Adam C, Delattre JY, Schmitt C, Guyot F, Chebbi I. Development of non-pyrogenic magnetosome minerals coated with poly-I-lysine leading to full disappearance of intracranial U87-Luc glioblastoma in $100 \%$ of treated mice using magnetic hyperthermia. Biomaterials. 2017;141:210-22.

26. Kobayashi SD, Voyich JM, Burlak C, DeLeo FR. Neutrophils in the innate immune response. Arch Immunol Ther Exp. 2005:53:505-17.

27. Granot Z, Jablonska J. Distinct functions of neutrophil in cancer and its. Regul Mediat Inflamm 2015; Art. ID: 701067.

28. Lévy M, Lagarde F, Maraloiu V-A, Blanchin M-G, Gendron F, Wilhelm C, Gazeau F. Degradability of superparamagnetic nanoparticles in a model of intracellular environment: follow-up of magnetic, structural and chemical properties. Nanotechnology. 2010;21:395103-14.

29. Zhang Y, Zhan X, Xiong J, Peng S, Huang W, Joshi R, Cai Y, Liu Y, Li R, Yuan K, Zhou N, Min W. Temperature-dependent cell death patterns induced by functionalized gold nanoparticle photothermal therapy in melanoma cells. Scientific Rep. 2018;8:8720.

\section{Publisher's Note}

Springer Nature remains neutral with regard to jurisdictional claims in published maps and institutional affiliations.
Ready to submit your research? Choose BMC and benefit from:

- fast, convenient online submission

- thorough peer review by experienced researchers in your field

- rapid publication on acceptance

- support for research data, including large and complex data types

- gold Open Access which fosters wider collaboration and increased citations

- maximum visibility for your research: over $100 \mathrm{M}$ website views per year

At BMC, research is always in progress.

Learn more biomedcentral.com/submissions 